\title{
Identification of root knot nematode in thippali
}

\author{
SEENA R. SUBHAGAN* AND SUSANNAMMA KURIAN ${ }^{1}$
}

Department of Vocational Higher Secondary, Government of Kerala, KERALA (INDIA)

${ }^{1}$ Department of Agricultural Entomology, College of Horticulture, Kerala Agricultural University, Vellanikkara, THRISSUR (KERALA) INDIA

\section{ARITCLE INFO}

Received : 07.03 .2016

Revised : 16.09 .2016

Accepted : 30.09 .2016

\section{KEY WORDS :}

Root knot nematode, Thippali, Medicinal plant, Aromatic plant, White females
*Corresponding author:

Email : seenarsubhagan@gmail.com; dhalindharan@gmail.com

\begin{abstract}
Thippali, Piper longum, is an important medicinal plant belonging to the family Piperaceae. An increase in root knot nematode attack was observed in thippali growing plots in Kerala. But the nematode species has not been identified. The study was conducted to identify the root knot nematode attacking thippali at Department of Agricultural Entomology, College of Horticulture, Kerala Agricultural University, Vellanikkara, Thrissur, Kerala. The study was undertaken by collecting soil and root samples from thippali growing plots already infested with root knot nematode. The species of root knot nematodes were identified by the perineal pattern of white females collected from root galls. The white females collected from the infested roots were sent to Department of Nematology, Indian Agricultural Research Institute, New Delhi for species identification. The species of root knot nematode attacking thippali was identified as Meloidogyne arenaria. This is the first report on attack of M. arenaria on thippali from India.
\end{abstract}

How to view point the article : Subhagan, Seena R. and Kurian, Susannamma (2016). Identification of root knot nematode in thippali. Internat. J. Plant Protec., 9(2) : 611-614, DOI : 10.15740/HAS/IJPP/9.2/611-614. 